\title{
Comparative phylogenies and host specialization in the alder ectomycorrhizal fungi Alnicola, Alpova and Lactarius (Basidiomycota) in Europe
}

\author{
Juliette Rochet ${ }^{1,2}$, Pierre-Arthur Moreau ${ }^{3}$, Sophie Manzi ${ }^{1,2}$, Monique Gardes ${ }^{1,2^{*}}$
}

\begin{abstract}
Background: Mycorrhizal fungi form intimate associations with their host plants that constitute their carbon resource and habitat. Alnus spp. (Betulaceae) are known to host an exceptional species-poor and specialized ectomycorrhizal (ECM) fungal community compared to other tree species, but the host-specificity pattern and its significance in terms of fungal diversification and speciation remain poorly documented. The degree of parallel speciation, host switching, and patterns of biogeography were explored in the historical associations between alders and three ECM taxa of Basidiomycetes: Alnicola (Agaricales), Alpova (Boletales), and Lactarius (Russulales). The aim was to develop an evolutionary framework on host specificity and diversification of Basidiomycetes in this highly specialized plant-fungus symbiosis.

Results: Sporocarps of Alnicola (220), Lactarius (61) and Alpova (29) were collected from stands of the four European alder species (A. alnobetula including the endemic subsp. suaveolens in Corsica, A. cordata, A. glutinosa, A. incana) in Western Europe (mainly in France and Austria), from 1995 to 2009. Specimens were morphologically identified to the species level. From these, 402 sequences of four DNA regions (ITS, rpb2, gpd, and the V9 domain of the mit-SSU rDNA) were successfully obtained and analyzed in addition with 89 sequences available in GenBank and UNITE databases. Phylogenetic analyses were conducted on all sequence data sets (individual and combined) using maximum likelihood reconstruction and Bayesian inference. Fungal phylogenies are compared and discussed in relation to the host, with a focus on species boundaries by associating taxonomic, systematic and molecular information.

Conclusions: Patterns of host specificity and phylogenies of Alnicola and Lactarius suggest coevolution as a basal factor of speciation in relation with the subgeneric diversification of Alnus, possibly due to the very selective pressure of the host. A second element of the historical associations between Alnus and its fungal symbionts is a host-dependent speciation (radiation without host change), here observed in Alnicola and Alpova in relation with Alnus subgen. Alnus. Finally host shifts from Alnus subgen. Alnus to A. alnobetula are found in most lineages of Alnicola (at least four times), Alpova (twice) and Lactarius (once), but they do not represent such a common event as could be expected by geographic proximity of trees from the two subgenera. However, active or very recent host extensions clearly occurred in Corsica, where some fungi usually associated with Alnus glutinosa on mainland Europe locally extend there to A. alnobetula subsp. suaveolens without significant genetic or morphological deviation.
\end{abstract}

\footnotetext{
* Correspondence: monique.gardes@univ-tlse3.fr

'Université de Toulouse, UPS, UMR 5174 EDB (Laboratoire Evolution et Diversité Biologique), 118 route de Narbonne, 31062 Toulouse Cedex 4 France

Full list of author information is available at the end of the article
} 


\section{Background}

In the ectomycorrhizal (ECM) symbiosis, the root system of an individual tree is typically colonized by several members of different ECM fungal species, and individual fungi can normally associate with several plants [1]. Ectomycorrhizal fungi display a great range of host specificity $[2,3]$. This varies from extremes such as Suilloideae that are almost exclusively associated with Pinaceae [4] with the example of the very host-specific Suillus pungens colonizing one or few related pine species [5], to species as Laccaria amethystina that demonstrate a true multihost ability [3]. The tight affinity between many ECM fungal species and their hosts has led to host-based taxonomic treatments in certain genera, e.g. Leccinum [6], and implicitly suggests that the phylogeny of the fungi follows that of their host plants, a process commonly known as coevolution [7]. Two main categories of events can be proposed to explain highly specialized associations between a plant and a fungal symbiont: (i) cospeciation/codivergence events where a symbiont speciates in response to the speciation of its host (association by descent), the phylogenetic outcome is congruent phylogenies of interacting taxa, and (ii) speciation through host shifts where the symbiont switches from the ancestral host to a new, unrelated host species (association by colonization); the phylogeny of the symbiont is influenced by the host evolution, but it is not reciprocal. Both processes suggest that host diversity, if not necessarily the sole cause of reproductive isolation and speciation, may force diversification and speciation of their symbionts. Host specificity is generally expressed as a symbiont's adaptation to a particular host species or higher taxa. The model investigated in the present study is the ectomycorrhizal symbiosis between the alder genus Alnus Mill. (Betulaceae) and three genera of Basidiomycota.

Based on fossil pollen evidence, the plant genus Alnus would have originated from tropical Eastern Asia around the Late Cretaceous [8], and it is likely that it reached Europe during early Oligocene. It was diversified in central Europe tropical forests by the end of Oligocene - early Miocene [9], and adapted to temperate and subarctic environments at the Miocene period [8]. Species of Alnus are now distributed in temperate and arctic regions of the Northern Hemisphere, except A. acuminata Kunth (sensu lato, including $A$. jorullensis Kunth) that extends as far South as South America. There are 29-35 species of Alnus is the current flora, with 4-5 species in Europe, 9 in the New World, and 18-23 in Asia $[8,10,11]$. Alnus consists of three clades $[11,12]$ including one subgenus not represented in Europe (subgen. Clethropsis), and two widely distributed subgenera Alnobetula and Alnus. The subgenus Alnobetula (also described as genus Duschekia Opiz) is sister to subgenera Clethropsis and Alnus, and likely the most primitive one [11-13]. It is represented, according to authors, either by a single thicket-forming circumpolar species: Alnus alnobetula (Ehrh.) K.Koch [also known as $A$. viridis (Chaix) DC.] divided into geographical subspecies $[8,10]$, or by several allopatric or parapatric species $[11,12]) ;$ A alnobetula was already present in France at the late Miocene, about 5.34 My ago [14]. The second main lineage (subgenus Alnus) is represented by numerous species in Eastern and Central Asia, with radiations towards North and South America, Europe, the Mediterranean basin and Eastern Asia, differentiated during Pleistocene. In subgen. Alnus, A. glutinosa (L.) Gaertn is a European and North African endemic species, present from W Europe and N Maghreb to Fennoscandia; pollen records and molecular data have revealed distinct major southern refuges in the last ice age, including W France, Corsica, S Italy, N Africa, Carpathians, and Turkey $[15,16]$. Alnus incana (L.) Moench is distributed across the cooler parts of Europe, mainly in Northern Europe and high elevation mountains in the Alps, the Carpathians and the Caucasus. Alnus cordata (Loisel) Duby is a Tyrrhenian endemic species that was isolated during the Pleistocene in Corsica and in a few other Mediterranean ice-free areas (Southern Italy, Albany) $[17,18]$ where it remained confined since its massive introduction for forestry all over Europe during the late $20^{\text {th }}$ century.

After the Quaternary glaciations the circumpolar species Alnus alnobetula and A. incana expanded in continental Europe (throughout Alps and Carpathians for A. alnobetula, up to Eastern France and Scandinavia for A. incana) from several refugia located in Central and Eastern Europe [10,19], while A. alnobetula subsp. suaveolens (Req.) Lambinon \& Kerguélen likely evolved isolated as an endemic subspecies in Corsica since the Pleistocene [20,21].

From analysis of mycorrhizae [22-27] alder trees have revealed an exceptional species-poor assemblage of ECM fungi compared to the other tree species, with less than 50 fungal species (including unidentified taxa) reported worldwide in the literature on $A$. acuminata, A. alnobetula s. lat., A. glutinosa, A. incana s. lat., and A. rubra. The fungal communities are dominated by six Basidiomycete genera, whatever the species of Alnus considered: Tomentella (12-15 spp.), Alnicola (15-20 spp.), Lactarius (5-8 spp.), Cortinarius (6-10 spp.), Alpova/Melanogaster [28] (6 spp.), and Russula (2-4 spp.). The fruiting community is also composed of two locally abundant taxa, Paxillus (1-2 spp.) and Gyrodon (1 sp.), rarely found from mycorrhizae analysis (Rochet et al., unpublished results). Other occasionally reported genera are Amanita (A. friabilis), Hebeloma, Inocybe, Pachyphloeus, Pseudotomentella, and unidentified 
Helotiales (possibly root endophytes). The Alnus-ECM fungi association is considered the most specialized ECM symbiosis. Except Tomentella spp. (for which precise taxonomic information is lacking) and several species of Ascomycota [26], all species are known, or strongly suspected, to be exclusive to the genus Alnus since they have never been found on any other trees than alders at present. There are reports of species-poor and specialized ECM fungal community for the ectomycorrhizal larch tree Larix spp. and five-needle pines (e.g. Pinus cembra, P. strobus) [29-31]. High specificity patterns are also observed for many orchids and monotrope plants associated with ectomycorrhizal fungi [1].

For the mycorrhizal symbiosis, it is still an open question how associations between plants and fungi arise and how specificity occurs. One way would be geographical isolation of populations leading to a narrowing of host range and allopatric speciation. However, we hypothesize than in highly specialized associations such as the alder-ECM symbiosis, plants exert considerable selective pressure on their fungal symbionts and are major drivers of diversification. This hypothesis was evaluated here by documenting the history of AlnusECM fungi association and specificity through molecular phylogenetic reconstructions.

Strong host-specificity patterns in mutualistic as well as parasitic relationships suggest intuitively a narrow coevolutionary history between symbionts [7]. The degree of parallel speciation and host switching between alders and three ECM taxa of basidiomycetes are explored as well as patterns of biogeography, with aims to develop more specific hypotheses on the processes that contribute to the diversification of the fungal lineages. Our predictions were that (i) the association with subgenus Alnus, more "modern" than subgenus. Alnobetula, is a derived character (the speciation of the fungi is linked to the speciation of the host), or (ii) evolution of a fungal symbiont would lead to increased specialization (there is an ongoing process of speciation by adaptation to new hosts).

The fungal lineages, Alnicola sect. Alnicola [32], Alpova, and Lactarius, were selected on the following criteria: 1 ) are present with all species of Alnus (excluding Paxillus and Gyrodon for this reason, never reported with subgen. Alnobetula); 2) have well-defined species concept (excluding Cortinarius, Tomentella and Alnicola sect. Submelinoides [32] for this reason); 3) contain enough species to obtain an informative phylogenetic tree (excluding Russula and Amanita for this reason). Sequences from one to four DNA regions were analyzed, including the nuclear rDNA ITS, parts of the nuclear genes rpb2 and gpd, and the V9 domain of the mitochondrial SSU-rDNA. Phylogenetic relationships among the European alders (five species and subspecies) were investigated using the ITS and chloroplast MatK sequences.

\section{Results}

Host phylogeny and datation

The phylogeny based on the combined data sets from ITS and MatK (Figure 1; see also Additional file 1: list

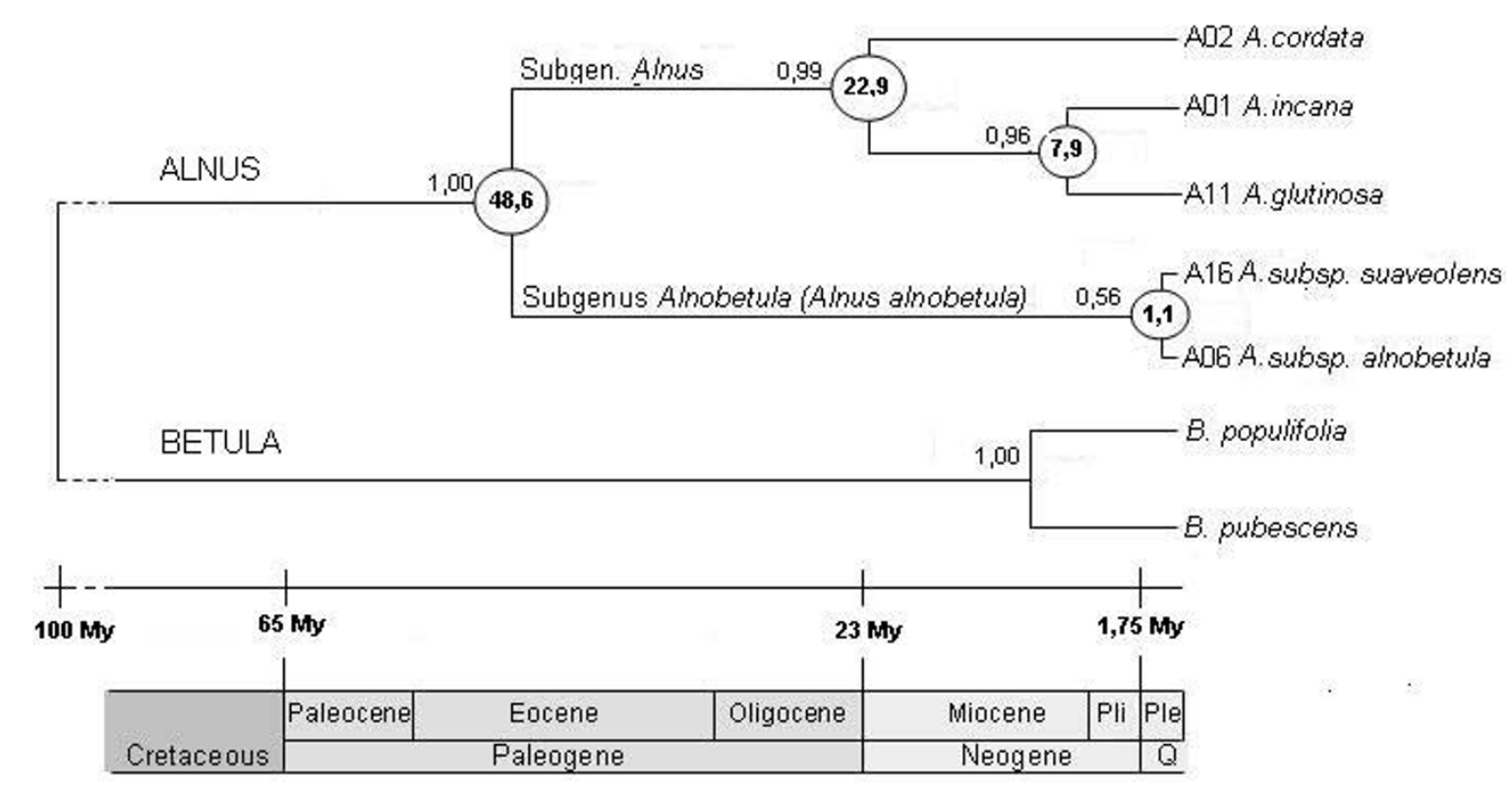

Figure 1 Bayesian cladogram inferred from nuclear rDNA ITS and chloroplastic region MatK sequences of Alnus spp. Numbers above branches are posterior probability scores. Numbers circled at the internodes are age in million years (My) estimated with Bayesian analysis implemented in BEAST software. The divergence between Alnus and Betula was assigned with an age of 95 to $105 \mathrm{My}$. 
of tree sequences used in this study) shows that European native species of Alnus are separated into two major clades that correspond to the subgenera Alnobetula and Alnus. Within the subgenus Alnobetula, $A$. alnobetula subsp. alnobetula and $A$. alnobetula subsp. suaveolens formed a monophyletic group. The subgenus Alnus clade comprises A. glutinosa and A. incana. Alnus cordata clusters outside this group. The multigene phylogeny confirms the relationship between the two Alnus clades with subgenus Alnobetula in a basal position. The molecular dating method gave the divergence between the two main subgenera of Alnus at the Eocene (around 48,6 My ago), and the original split between $A$. cordata and the A. glutinosaincana complex at the Oligocene (around 22,9 My ago; Figure 1). Results also suggest recent lineage diversification at the Pleistocene for both subgenera (around 1,1 and 7,9 My ago for subgenus Alnobetula and the A. glutinosa-incana complex, respectively; Figure 1).

\section{Alnicola phylogeny and reconstruction of the history of associations}

The ITS sequences for most Alnicola [abbreviated Alc. below] collections were complete (see Additional file 2: list of fungal sequences used in this study). However, the numbers of variable and informative characters of the ITS molecular dataset were very low (27 on ITS1 and 21 on ITS2 for the whole section, i.e. 14 species). Most species were separated from each other by 2 to 6 nucleotides at best. Only Alnicola pseudosalabertii collections group together in a strongly supported clade that is well separated from the other lineages [32]. However, fourteen infrageneric groups (clusters or phylogroups, interpreted here as phylogenetic species) are identified, that are congruent with existing morphological taxonomy (morphospecies) at least for well-documented taxa [33,34]. Six of them could not be identified to valid taxa and are here cited under provisional names (Alnicola badiofusca, Alc. citrinella, Alc. longicystis, Alc. pallidifolia, Alc. pseudosalabertii, Alc. xanthophylla).

Because the datasets of the four genes were highly congruent, a combined analysis was conducted on a 2743 bases long alignment, obtained by concatenation of all genes for each sampled morphospecies, with a Bayesian approach (Figure 2, 3, 4). Alnicola geraniolens Courtec., which belongs to Alnicola sect. Amarescens [33] (not associated with Alnus) was taken as an outgroup [32]. Alnicola cholea Kühner, in sect. Cholea P.A.

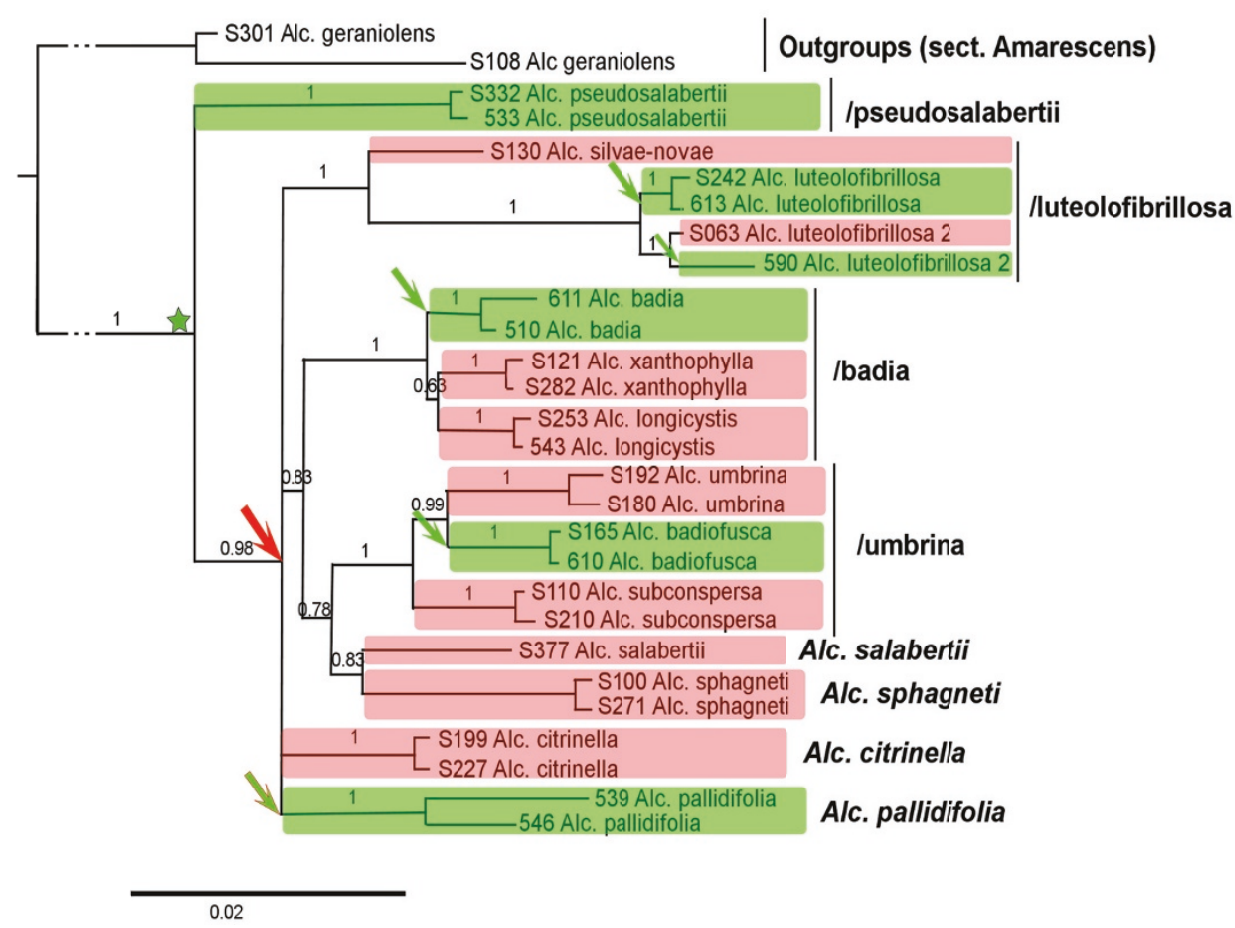

Figure 2 Phylogenetic reconstruction of the Alnicola sect. Alnicola lineage (Hymenogastraceae) by concatenate analysis (ITS, GPD, RPB2, V9), showing putative evolutional events in relation with host specificity. Red: species associated with Alnus sect. Alnus. Green: species associated with Alnus sect. Alnobetula. Green star shows putative basal association with Alnus alnobetula (possible co-speciation). Arrows show events of speciation associated with host specificity; red arrow: host-dependent radiation with Alnus subgen. Alnus; green arrow: host shifts from Alnus subgen. Alnus to A. alnobetula. 


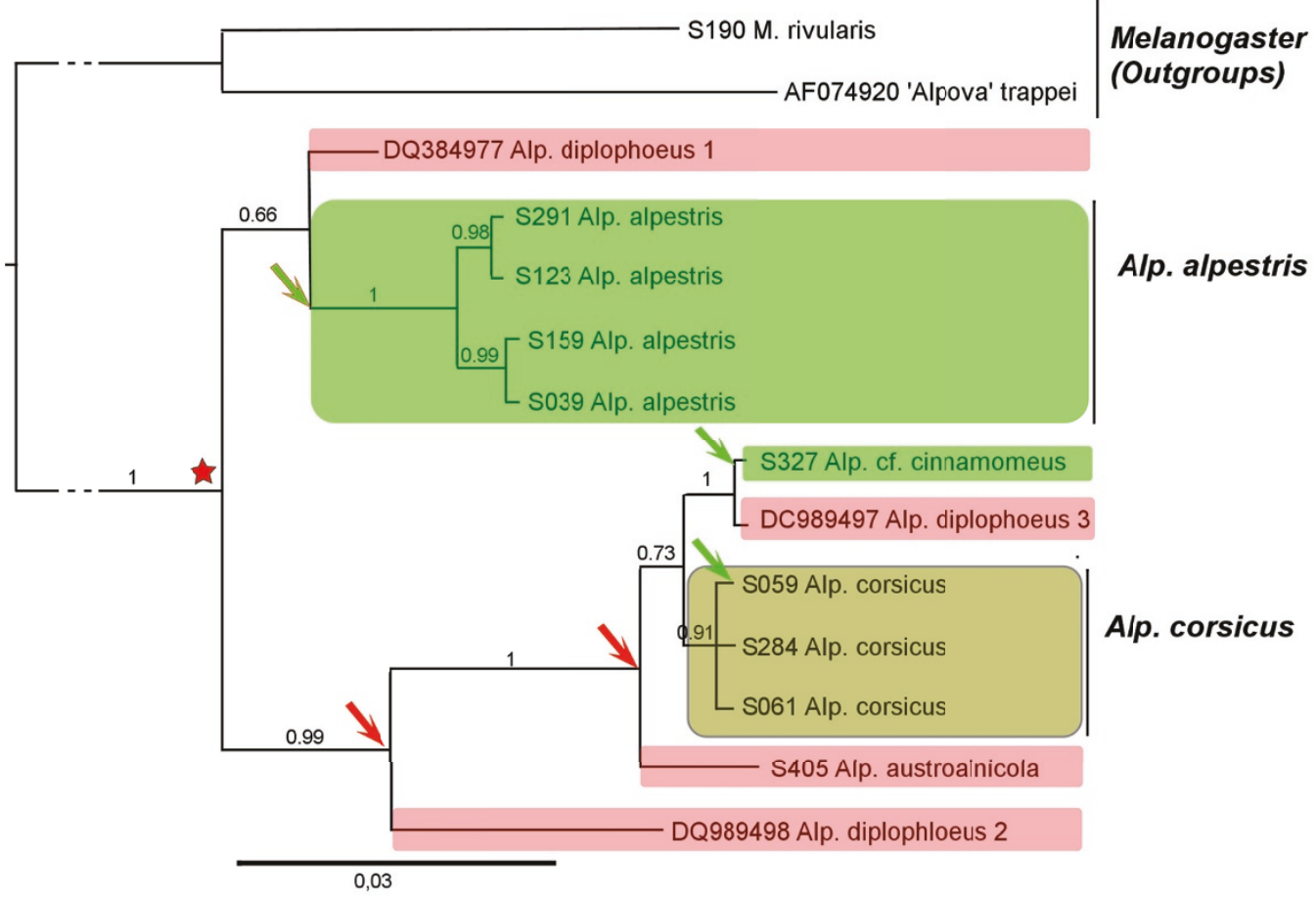

Figure 3 Phylogenetic reconstruction of the Alpova lineage (Paxillaceae) based on ITS, showing putative evolutional events in relation with host specificity. Red: species associated with Alnus sect. Alnus. Green: species associated with Alnus sect. Alnobetula. Brown: species associated with alders of both sections. Red star shows putative basal association with Alnus sect. Alnus. Arrows show events of speciation associated with host specificity; red arrow: host-dependent radiation with Alnus subgen. Alnus; green arrow: host shifts from Alnus subgen. Alnus to A. alnobetula.

Moreau [35], a more distant species not associated with Alnus, was also tested as outgroup but gave a weaker resolution on some branches (not shown). Although species relationships are still not completely resolved even when data from additional genes are included, the same fourteen species are clearly identified in all the analyses (each gene separately or the concatenated dataset), likely representing independently evolved lineages (Figure 2). The low sequence divergence and lack of phylogenetic resolution including with the combined gene dataset, suggests a fast radiation of these species in a short geological time.

The/pseudosalabertii clade is coming out as basal lineage amongst sect. Alnicola, with strong support in the concatenated analysis (Posterior Probability $=1$, Figure 2 ). It is only represented by a rare species, only known from a few sites under Alnus alnobetula in mineral-rich subalpine situations. It has distinctive morphological characters such as spore features and pileal microstructure (unpublished data) that are also present in the nonalnicolous species of Alnicola sect. Amarescens, but not in other species of sect. Alnicola. These ancestral characters are congruent with its basal position in the phylogeny of Alnicola section Alnicola. Alc. pseudosalabertii, a species strictly associated to subgenus Alnobetula, appears clearly as an ancestral lineage.

The/luteolofibrillosa lineage appears as a collective species (or as a species complex), represented in Europe by at least two genetically distinct lineages. The former, Alnicola luteolofibrillosa s. str., is strictly associated with Alnus alnobetula in the Alps. The later, here named Alc. luteolofibrillosa "2", is collected under Alnus sect. Alnus in Europe and North America. Suprisingly, Alc. luteolofibrillosa "2" is found also with Alnus alnobetula subsp. suaveolens in Corsica, where Alc. luteolofibrillosa s. str would be expected according to host specificity. Alnicola silvae-novae (D.A. Reid) Courtec., a rare species encountered with Alnus glutinosa, comes out in the same cluster as Alc. luteolofibrillosa (Figure 2).

The ancestral state in the/luteolofibrillosa lineage is subgenus Alnus, while the host switches to Alnobetula probably occurred via a generalist species and niche contraction or host-dependent speciation (duplication).

In the/badia lineage, three species, Alnicola badia Kühner with Alnus alnobetula, Alc. longicystis ad int. and Alc. xanthophylla ad int. with Alnus glutinosa and $A$. incana, group together with very little nucleotide variation (7-8 characteristic positions on ITS1-2). All three 


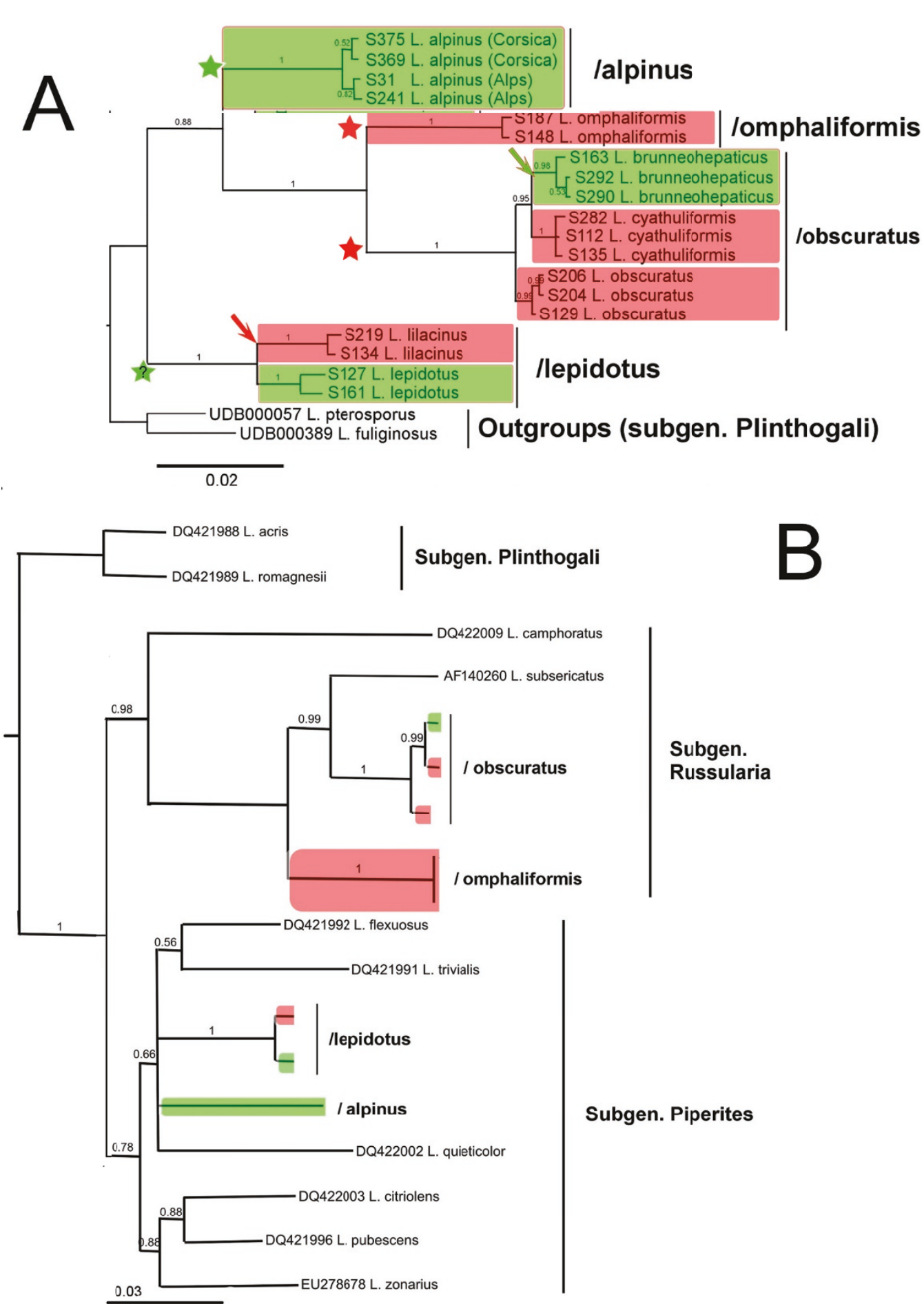

Figure 4 Phylogenetic reconstructions of the Lactarius lineage (Russulaceae) based on ITS, showing putative evolutional events in relation with host specificity. A: concatenate analysis of alnicolous species (ITS + RPB2 + V9). B: concatenate analysis (ITS + RPB2) of Lactarius subgen. Russulares showing positions of each clades of alnicolous species within the genus. Red: species associated with Alnus sect. Alnus:; Green: species associated with Alnus sect. Alnobetula. Green and red stars show putative basal association with Alnus sect. Alnobetula (with possible cospeciation) and sect. Alnus respectively. Arrows show events of speciation associated with host specificity; red arrow: host-dependent radiation with Alnus subgen. Alnus; green arrow: host shifts from Alnus subgen. Alnus to A. alnobetula. 
are apparently restricted to specific soil conditions, e.g. sands and alluvial substrates.

The/umbrina lineage contains Alnicola subconspersa (P.D. Orton) Bon, Alc. umbrina (Maire) Kühner, and Alc. badiofusca ad int., that are three abundant fruiting species in alder stands. Both Alc. subconspersa and Alc. umbrina are associated with Alnus glutinosa and occasionally with $A$. cordata and A. incana, while Alc. badiofusca is found under Alnus alnobetula. In the present study, Alnicola dubis P.-A. Moreau \& Vidonne is assimilated to Alc. subconspersa. Both Alc. striatula (P.D. Orton) Romagn. and Alc. scolecina (Fr.) Romagn. s. auct. [36] are assimilated to Alc. umbrina. Despite a recognition of Alc. dubis, Alc. striatula and Alc. scolecina in traditional taxonomy [34], these three species are temporarily grouped with the previous ones because of weak morphological support and only 1-2 nucleotide differences in the ITS sequences. These provisional taxonomic choices do not influence the results of our analysis since these taxa share the same host (Alnus glutinosa). However, taxonomy in this lineage obviously remains to be precised.

Finally four distinct species that comprise Alnicola citrinella (Alc. escharioides (Fr.: Fr.) Romagn. s. auct. pl.) with Alnus glutinosa and A. incana, Alc. pallidifolia with A. alnobetula, Alc. salabertii P.-A. Moreau \& Guy Garcia with A. cordata [37], and Alc. sphagneti (P.D. Orton) Romagn., are also difficult to position in the phylogeny. However, they are characterized by distinctive morphological and ecological characters as well as nucleotide differences in the ITS and the other gene regions. Alc. sphagneti is associated with Alnus glutinosa, and apparently restricted to North Atlantic acidic localities; in the phylogenetic analyses, it comes out at the basis of the/umbrina lineage (Figure 2).

\section{Alpova phylogeny}

The monophyletism of both genera Alpova [abbreviated Alp. below] and Melanogaster [28] is strongly supported by both ITS $(\mathrm{PP}=1)$ and multigene phylogenies (Figure 3 ), and these results are consistent with previous studies $[38,39]$. Melanogaster is here taken as outgroup [40] to root the Alpova phylogeny. The relationships among the Alpova species were also well resolved with both phylogenies (not shown). Because Alpova appears as a genus with a reduced diversity in Europe (three species, Figure 3) the analysis was extended to extra-European species of Alpova, and phylogenetic reconstructions performed using ITS sequences.

Phylogenetic analysis of the ITS dataset clearly splits Alpova into two strongly supported clades, both including North American and European species (Figure 3). The first clade $(\mathrm{PP}=0,83)$ contains an unidentified American taxon, Alpova "diplophloeus 1", in a basal position, while Alp. alpestris, a European species often encountered under Alnus alnobetula in the Alps, Carpathians and Corsica, is placed in a derived position. No significant molecular difference was found among continental collections of Alp. alpestris (represented by 9 sporocarps from 4 localities, all located in the French Alps). The two Corsican collections (3 sporocarps from 2 localities) are separated from the mainland collections by 9 nucleotide positions: two in the ITS1, one in RPB2 and 6 in GPD. The second clade (PP $=1)$ is rooted by another unidentified American taxon (Alp. "diplophloeus 2 ") and the South American Alp. austroalnicola associated with Alnus acuminata s.lat. (subgenus Alnus). It comprises three derived taxa that are the Corsican endemic Alp. corsicus (non host-specific but mainly with subgenus Alnus), Alp. "diplophloeus 3" (DQ989497) under Alnus incana, and a European collection (Alp. cf. cinnamomeus) that has been found so far under A. alnobetula.

The case of Alpova corsicus deserves a particular attention as this species, represented here by 8 sporocarp collections from 6 sites in Corsica (see Additional file 2: list of fungal sequences used in this study) and one sequence from mycorrhiza (not shown), appears restricted to the island of Corsica. When found, it fruits abundantly under Alnus glutinosa in riparian and peaty forests, but also under $A$. cordata at supramediterranean level, and more occasionally under $A$. alnobetula subsp. suaveolens (one single collection with longer spores) [28]. Remarkably, our numerous prospects under A. glutinosa or A. incana in continental France never showed us any basidiome of Alpova. In addition to the information provided by sporocarp surveys, molecular studies of ECM communities have not revealed so far the presence of Alpova species in alder stands of A. glutinosa or A. incana elsewhere in continental Europe. The few reports of Alpova sporocarps from Alnus incana and A. glutinosa in central Europe are referred to Melanogaster luteus $[28,41]$.

\section{Lactarius phylogeny}

Collections of Alnus-associated Lactarius are grouped in four independent lineages, based on the combined molecular phylogeny of ITS and rpb2 sequences (Figure 4A, 4B) as well as on separated gene phylogenies (not shown). The internal systematics of Lactarius is still insufficiently documented and the nomenclature of subgenera and sections follows the most recent phylogenetic assessment of the whole genus [42,43]; Alnus-associated species belong to subgen. Piperites and subgen. Russulares which form together a monophyletic lineage. Subgenus Plinthogali is taken as outgroup for rooting the Piperites-Russulares phylogeny [42]. 
The/lepidotus lineage contains two species that are Lactarius lepidotus Hesler \& A.H. Sm. strictly associated with Alnus alnobetula, and L. lilacinus (Lasch: Fr.) Fr. associated with $A$. glutinosa and A. incana. The two species are closely related despite strong morphological differences. Both are usually classified by taxonomists in subsection Coloratini (including species such as L. helvus, L. glyciosmus, and L. alpinus) due to the presence of typical dry squamulose pileus [44], but here surprisingly, they show genetic affinities with several groups with gelatinized pileus (ixocutis) of subgen. Piperites, represented in the phylogeny by sect. Deliciosi (L. quieticolor) (Figure 4B).

All collections of $L$. alpinus Peck, from the Alps and Corsica, group together with other species of Lactarius from subgen. Piperites, sect. Glutinosi, surprinsingly without close relationship with $L$. lepidotus despite morphological affinities (Figure 4B).

L. alpinus is associated to Alnus alnobetula and has been reported worldwide in the distribution range of its host, e.g. in N.E. USA, Alaska, Greenland, Carpathian Mountains [44,45]. L. alpinus var. mitis Hesler \& A.H. $\mathrm{Sm}$. is known from alder trees (subgen. Alnus) in Western U.S.A. [45], and might represent a possible host-shifted vicariant of L. alpinus; unfortunately no DNA sequence or reliable dry material could be obtained.

The two remaining lineages (/omphaliformis and/ obscuratus) are more modern than the previous ones, coming out from a species-rich group of small Lactarius (subgen. Russularia) mostly common in temperatesubarctic areas, such as L. tabidus (Fr.: Fr.) Fr., L. subsericatus Bon, or L. aurantiacus Fr., and strongly hostspecific such as L. subdulcis (Fr.: Fr.) Fr. (restricted to Fagus) and L. hepaticus Plowr. (restricted to Pinus).

L. omphaliformis Romagn. forms a single clade that is genetically very stable, and surprisingly comprises a sequence obtained from Alnus acuminata in Argentina (GenBank DQ195543). In Europe, L. omphaliformis has been reported from the West under A. glutinosa in typically acidic situations, but it might be a cosmopolitan species associated with more species of Alnus sect. Alnus worldwide. The lack of reports under $A$. incana could be due to narrow biogeographical and edaphic preferences, not compatible with the natural distribution of the host in Europe. It is also one of the very few symbiotic species of Alnus sect. Alnus for which no relative species is known on $A$. alnobetula.

The/obscuratus lineage is composed of morphologically highly variable and taxonomically confused taxa (Figure 4A). Six distinct species or varieties are recognized by mycologists $[44,46,47]$ and many names are usually cited in literature (e.g. L. obscuratus Lasch: Fr., L. cyathuliformis Bon, L. clethrophilus Romagn., L. brunneohepaticus M.M. Moser, L. obscuratus var. radiatus (J.E. Lange) Romagn., L. obscuratus var. subalpinus
Basso, L. radiatus var. alnobetulae Bon). In the present study, three well-separated phylogroups are identified with a clear host specificity (Figure 4A) Both L. obscuratus s. str. (including L. clethrophilus) and L. cyathuliformis are found in association with A. glutinosa, A. incana and $A$. cordata, while $L$. brunneohepaticus (including L. obscuratus var. subalpinus) is associated with $A$. alnobetula in the Alps and Corsica.

\section{Discussion}

\section{Looking for early speciation events}

The ancestral position of subgenus Alnobetula inferred from worldwide molecular phylogenies of alders $[11,12]$ is confirmed by our results. Our molecular clock estimates are consistent with the fossil records that suggest an extant ancestor of $A$. cordata-glutinosa-incana at the Oligocene (around 22,9 Mya) and recent radiation events at the Pleistocene in the subgenus Alnobetula and the glutinosa-incana complex (Figure 1). A low sequence divergence was also cited [11] in the ITS region within the subgenus Alnobetula and the A. incana species complex (including A. glutinosa), indicating recent diversification in the circumpolar areas.

Alnicola is the most informative genus thanks to its species richness. Since no supraspecific classification in sect. Alnicola has been proposed so far in taxonomic literature, the present phylogeny will contribute to a better systematic and taxonomic treatment of the genus (unpublished results). Alnicola pseudosalabertii, a species with ancestral morphological characters, is likely the oldest known Alnus-associated species in the Hymenogastraceae family. Its basal position in the Alnicola phylogeny suggests a common origin of the Alnusassociated fungal lineage and the most ancestral Alnus lineage, and therefore a synchrony in the occurrence of both lineages. However, the absence of fossils or standardized molecular clock in fungi did not allow us to test the time concordance between the plant and the fungal lineages.

In Lactarius, the two oldest Alnus-associated lineages root at the basal origin of temperate Lactarii (Figure 4B) and are likely to find their origin at the same early period of emergence of temperate-subarctic Alnus species of subgen. Alnobetula [48]. This is congruent with the fact that Lactarius lepidotus (/lepidotus) and $L$. alpinus (/alpinus), two widespread species with ancestral morphological characters in the genus (dry trichodermial pileus structure) are strictly associated with Alnus alnobetula worldwide. L. lilacinus, here appearing as a sister clade of L. lepidotus (Figure 4A), would be an example of phylogenetic speciation with Alnus sect. Alnus if it could be shown to derive from L. lepidotus.

In Alpova, the two species currently known to be associated with Alnus alnobetula (Alp. alpestris and Alp. 
aff. cinnamomeus) are in derived position in the phylogeny (Figure 3), and therefore do not illustrate any co-evolutive pattern (but information is lacking about host identity of North American species). Hypothesis of a recent emergence of the Alpova lineage with Alnus sect. Alnus cannot be excluded. The alternative hypothesis is an older origin of Alpova with Alnus alnobetula with host-shift and later radiation with Alnus sect. Alnus. If so, then ancestral species that would be analogous to Alnicola pseudosalabertii in the Alnicola phylogeny, should be found under Alnus alnobetula in and outside Europe.

\section{Recent host-dependent evolution processes}

If the hypothesis of co-speciation could explain the basal topology of the oldest Alnus-associated lineages such as/ pseudosalabertii (Alnicola),/lepidotus (Lactarius) and/ alpinus (Lactarius), the prediction of a specific diversity only driven by co-evolution processes in which ancestral species would be associated to Alnus alnobetula, and recent lineages to Alnus glutinosa-A. incana, is clearly not congruent with the current species diversity observed in Alnus-associated communities. Except Lactarius species (L. alpinus and L. lepidotus) which are still dominant in Alnus alnobetula ecosystems, most ECM fungal species currently dominating the community (such as Alpova alpestris, Lactarius brunneohepaticus, Alnicola badia, Alc. badiofusca, Alc. luteolofibrillosa) are derived from fungal lineages evolved with Alnus sect. Alnus (Figure 1). In Alnicola, the main current diversity likely appears during a fast radiation period. It is tempting to compare this diversification event to the fast radiation period of Alnus during the Pleistocene [11,12], which suggests that recent lineages of fungi show the same evolutionary patterns that Alnus sect. Alnus. Similarly to Betula-associated Leccinum species (Boletales) [6], the most plausible mechanism for this diversification event is allopatric speciation with isolation of fungal populations in glacial refuges of their host at the Pleistocene.

\section{Host shifts but not host extension?}

The two hypotheses previously suggested - early co-evolution with Alnus sect. Alnobetula, and later hostdependent speciation with Alnus sect. Alnus, explain correctly most of the topology of the three fungal genera, but the presence in derived branches of species associated with Alnus alnobetula - not explained by any co-evolution scheme - suggests another factor of hostdependent speciation. Most species associated with Alnus alnobetula derived from lineages associated to Alnus sect. Alnus (e.g. Alnicola badia in the/badia lineage, and Alc. badiofusca in the/umbrina lineage; Lactarius brunneohepaticus in the/obscuratus lineage; and
Alpova alpestris derived from Alnus sect. Alnus associated species). The only explanation for so many examples of recent Alnobetula-associated species of ECM fungi is recent host-shifts that have occurred independently in most fungal lineages, from modern species of Alnus subgen. Alnus to A. alnobetula, followed by a fast host-dependent speciation. Interestingly enough, no example has been found of host shift from Alnus alnobetula to A. glutinosa/A. incana hosts. This unilateral phenomenon suggests that environmental pressure or promiscuity of different species of Alnus cannot explain completely such host-shift phenomena, which certainly implies important genetic mechanisms of host recognition so far unidentified.

\section{What Corsica tells us about host shifts}

The geographic co-expansion of Alnus alnobetula and $A$. incana throughout their distribution area since the Pleistocene [11] and their frequent co-occurrence in the same geographical areas (e.g. in the Alps where A. alnobetula and A. incana co-exist and grow locally intermixed) create environmental contexts that should facilitate host-shifts. If colonization of new hosts is more a matter of geographic proximity than relatedness of the hosts, then numerous derived species and unsolved species complexes would be expected. The results show that recent jumps to distantly related hosts (from different subgenera) are relatively infrequent and limited to one "shifted" new species per lineage (see above). Fungal species with broad host range are not observed in derived positions of the three fungal phylogenies. All studied species are well resolved at specific level and highly host-specific at the level of plant subgenus (even when collected in sites where alders from the two subgenera grow adjacent to each other, as shown by molecular analysis of mycorrhizae, Rochet et al. unpublished data). This pattern of host-symbiont association is also observed in 'Alnicola' sect. Submelinoides [32 and unpublished data], Russula (J. Borovička, unpublished data), Cortinarius [30], and several other genera [49]. By contrast, colonization of close relatives within each subgenus of Alnus is occurring frequently, possibly explained by host tracking through hybrids. Thus, the same species of ECM fungi are commonly found under A. glutinosa and $A$. incana, two alder species for which natural hybridization has been reported in the boundaries of their distribution areas [50]. Such a scenario of host-tracking coevolution (that could eventually lead to speciation) have been nicely shown between Puccinia rust fungi and their crucifer (Brassicaceae) hosts [51].

Corsica is a remarkable exception to this general pattern of host-symbiont association. Thus, host jumping to distantly related hosts appears to be facilitated in Corsica because there are at least three species of fungi 
that are commonly found under A. glutinosa (A. incana never existed in Corsica) and $A$. alnobetula subsp. suaveolens, despite the geographical distance between collections from the two hosts (at least $10 \mathrm{~km}$ apart from each other). The generalist species are Alnicola luteolofibrillosa "2" (with an already perceptible genetic divergence of 2 nucleotide positions on ITS1 between A. glutinosa- and A. alnobetula subsp. suaveolensassociated populations), Alpova corsicus [28], and "Alnicola" inculta (Peck) Singer (sect. Submelinoides, not treated in this study) present in Corsica under A. alnobetula but never found or reported from the Alps under this tree so far.

It is likely that the speciation process by host shift which led to the differentiation of most Alnus alnobetula-associated fungi from Alnus incana-glutinosa -associated lineages, is still active, or at last much more recent or less advanced, in Corsica where the three examples cited above seem to illustrate a case of "host extension" preceding speciation. In contrast to the "Leccinum model" [6], "host extension" here does not extend to unrelated new hosts but to another species of Alnus, and is probably favoured by tree promiscuity as well as by insularity and genetic isolation from the continent. More examples would have to be looked for in other areas of Quaternarian glacial refugia where A. glutinosal $A$. incana and $A$. alnobetula still co-exist, e.g. in Eastern Europe or Caucasus. As real islands provide an opportunity to examine the factors causing evolution in ECM fungi [52], fine-scale genetic structure of the fungal species present on the mainland, Corsica, and other host Mediterranean islands (e.g. Sardinia) should also be pursued in future studies.

\section{The Alnus-ECM fungal symbiosis: a powerful model for the study of speciation of ECM fungi}

The factors driving ECM diversity in terms of speciation processes remain poorly documented, and only a few examples have been satisfactorily investigated. The interactions between alders and ectomycorrhizal fungi appear highly specialized, and as a consequence when hosts undergo certain selection regimes, their symbionts might also take evolutionary steps to maximize their fitness. The evolutionary framework developed in this study gives an alternative to the cyclic-biphasic model developed on Leccinum (ECM Boletales) [6], which implies more or less soft periods of host contractions and extensions driven by environmental changes, in which coevolution does not act significantly.

Because coevolutionary events become masked through time via host switching, extinction and duplication, finding empirical evidence for co-speciation (or codivergence) patterns has proven difficult in many groups of organisms, including classical examples of animal parasites. However, possibly due to the very selective pressure of the host, ECM coevolution appears in Alnicola and in Lactarius as a basal factor of speciation in these genera in relation with the subgeneric diversification of Alnus. More investigations on extra-European Alnus-associated communities are necessary to fill the phylogenetic puzzle in all these genera and confirm the reality of this early speciation process. Evidence for ongoing local coevolutionary selection could also be obtained by experimental pairings between plant and fungal populations [53].

The second element of the historical associations between plants and fungal symbionts is a host-dependent speciation (radiation without host change), suggested marginally [6] for explaining the radiation of a Betula-associated group of Leccinum, here observed clearly in Alnicola and Alpova in relation with Alnus sect. Alnus; allopatry is a possible cause of genetic isolation of populations evolving quickly as genetically distinct species (detectable by unsolved rake-like clades). This phenomenon of Pleistocene origin might have driven active speciation processes in relation with Alnus sect. Alnus. A fine-scale genetic study of common fungal species associated e.g. with Alnus glutinosa [15] in its glaciation refugia such as Spain, North Africa, Corsica, Balkans and Turkey, would help quantifying local hostdependent diversification processes in fungi, migration and interbreeding processes at a continental scale, and extrapolate them to more ancient speciation events.

Host shifts from Alnus alnobetula to subgen. Alnus are observed in most lineages of Alnicola (at least four times), Alpova (twice) and Lactarius (once) (Figure 2, 3, 4), but they do not represent such a common event as could be expected by current geographic proximity of trees from the two subgenera, or by their assumed promiscuity in Pleistocene refuges. Other, probably rare factors are necessarily involved to explain this phenomenon. Host shift is likely a consequence of past host extension; in our study we have identified active or very recent host extensions in Corsica, of fungi usually associated with Alnus glutinosa locally extending to A. alnobetula subsp. suaveolens without significant genetic or morphological deviation. In Corsica the current coexistence of these trees at short distance, and even their close promiscuity during glaciations events, are reinforced by insularity and confinement in narrow valleys. In the Alps this phenomenon might be older than in Corsica, since sister species associated with A. alnobetula are genetically and morphologically well differentiated from those associated to the A. glutinosa-A. incana complex.

\section{Conclusions}

Although extreme specialization may represent an evolutionary-dead-end, host-dependent speciation seems to 
have played a more important role than host shift across large phylogenetic distances in the evolution of the studied fungi, as especially illustrated by Alnicola, the most species-rich studied group. The Alnus-EcM fungi communities are a unique model for reconstituting the events of speciation amongst symbiotic fungi. Fungal assemblages associated with alders comprise other genera such as Tomentella (Thelephorales), Cortinarius (Agaricales), Paxillus (Boletales), Russula (Russulales), which will complete the present study.

Inferences about the evolutionary events of symbionts in the light of phylogenies are sensitive to the information at hand. By adding missing or newly discovered fungal species to the trees, especially from the numerous non-investigated alder species outside Europe, our picture about the details of coevolution or host switching may change. Advancing the work presented here would benefit from additional sampling of the fungi (sporocarps and mycorrhizae), particularly in areas that would introduce new host associations not represented here. Although estimation of the time of divergence of the clades will always be difficult in fungi due to the lack of fossils, what is also required is a comprehensive and well calibrated tree based on numerous molecular divergence rate estimates. Most such data are not available today. A concerted effort is thus necessary for understanding the evolution of Alnus-associated fungi, what in turn would greatly benefit to the understanding of the effects of evolutionary and historical events in the late Tertiary and Quaternary on the geographic distribution of ECM fungi in general [54], with transferability of this information to biodiversity studies and conservation programs.

The present study focused on historical events and coevolutionary relationships in explaining current patterns of host specificity in the Alnus ECM symbiosis. Further research is needed to shed light on the role of ecological parameters such as soil nitrogen conditions in shaping the distinct nature of Alnus ectomycorrhizal assemblages and the current distribution of the fungal species.

\section{Methods}

Taxonomic sampling

PLANTS

The four European native species of alders (= five species and subspecies) are listed in Additional file 1, along with the gene regions analyzed for each of them and GenBank accession numbers.

\section{BASIDIOMYCOTA}

Most fungal sequences used in this study are derived from extensive sporocarps sampling of Alnicola, Alpova and Lactarius conducted by PAM over several years. Sporocarps of 220 Alnicola, 61 Lactarius and 29 Alpova

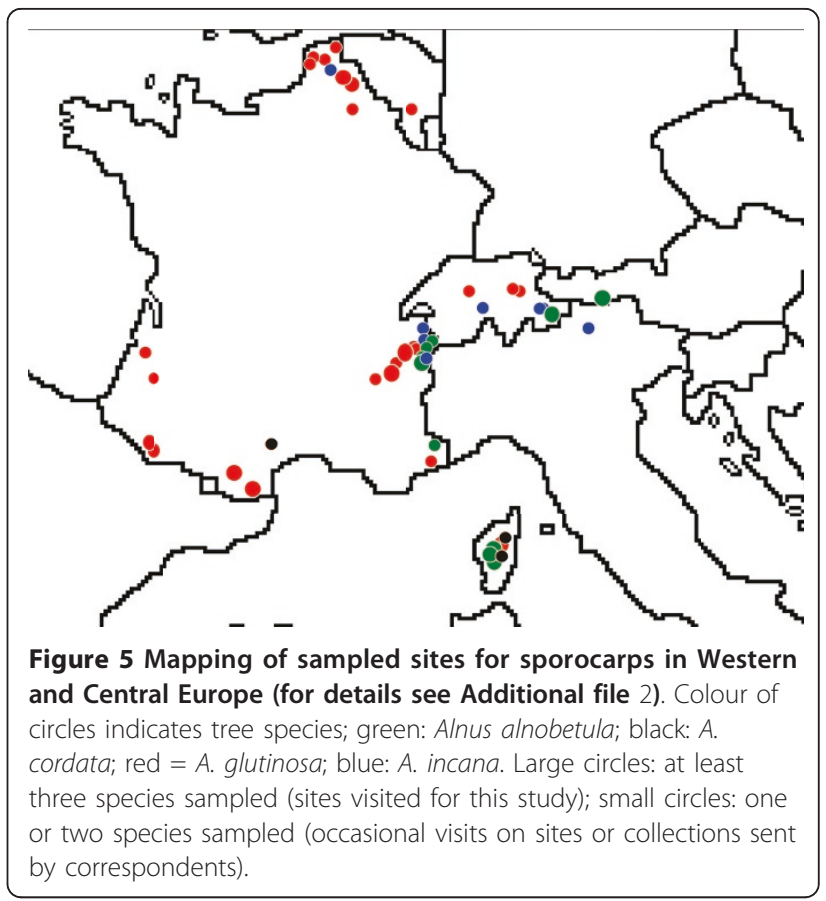

were collected from multiple stands of the four European alder species, at various locations in France and other European countries (especially Austria and Switzerland; Figure 5). In most cases, host could be designated unambiguously in the field, one species of alder trees being locally the only ECM host plants, but in a few cases the closest ECM host tree was design as the host plant. Molecular typing of ectomycorrhizae was also performed to confirm the identity of the host and the fungal symbiont (the results will be presented elsewhere). Tissue samples (gills or part of the fruitbody flesh) were stored in a CTAB 2X Buffer (100 mM Tris$\mathrm{HCl}(\mathrm{pH}$ 8), 1.4 M NaCl, $20 \mathrm{mM} \mathrm{Na} 2$ EDTA, $2 \%$ CTAB) until DNA extraction. Taxonomy and nomenclature follow [28] for Alpova, [42] for Lactarius, [34] and partly unpublished results for Alnicola. Voucher specimens are deposited at the Herbarium of the Faculté des Sciences Pharmaceutiques et Biologiques, Lille (LIP), France. The dataset also included sequences from earlier studies [32,55-57,42,58] and some unpublished sequences with reference material downloaded from public databases (GenBank, UNITE). Information regarding the sampling (species, host plant, geographic location, DNA and herbarium collection numbers, genes analyzed, GenBank accession numbers, references) is provided for all materials in Additional file 2: list of fungal sequences used in this study as supplementary data.

\section{DNA extraction, PCR amplification and sequencing}

Total DNA was extracted from Alnus leaves, CTAB samples and herbarium specimens of ECM fungi using 
the kit Wizard Genomic DNA Purification Kit (Promega) according to the manufacturer's protocol.

\section{PLANTS}

Two DNA regions were selected for the present Alnus phylogeny: the nuclear rDNA ITS and the chloroplastic region MatK. The PCR reaction mix included $0.2 \mu \mathrm{l}$ of GoTaq $5 \mathrm{U} / \mu \mathrm{l}$ (Promega), $10 \mu \mathrm{l}$ of $5 \mathrm{X}$ buffer, $1 \mu \mathrm{l}$ of $20 \mu \mathrm{M}$ for each primer, $1 \mu \mathrm{l}$ of dNTP $10 \mathrm{mM}, 1 \mu \mathrm{l}$ of DNA template and nuclease free water for a final volume of $50 \mu \mathrm{l}$. Standard cycling parameters were an initial denaturation step at $94^{\circ} \mathrm{C}$ for 1 minute, 40 cycles of denaturation at $94^{\circ} \mathrm{C}$ for $30 \mathrm{~s}$, annealing for $40 \mathrm{~s}$ at different temperatures depending on the primer set $\left(57^{\circ} \mathrm{C}\right.$ for ITS, $46^{\circ} \mathrm{C}$ for matK) and elongation at $72^{\circ} \mathrm{C}$ for $40 \mathrm{~s}$, followed by a final elongation step at $72^{\circ} \mathrm{C}$ for $5 \mathrm{~min}$.

\section{BASIDIOMYCOTA}

One to four regions were amplified and sequenced depending on the genus and sample. The DNA regions and primers used for PCR are the nuclear rDNA ITS using the primer set ITS-1F/ITS-4B [59], the rpb2 gene using bRPB2-5F/bRPB2-7.1R [60], the gpd gene using GPD-F/GPD-RA $[61,62]$, and the hyper variable domain V9 of the mitochondrial SSU-rDNA using the V9U/V9R $[63,64]$.

Amplifications were carried out in $25 \mu \mathrm{l}$ reaction containing $0,2 \mu \mathrm{l}$ of GoTaq polymerase of $5 \mathrm{U} / \mu \mathrm{l}$ (Promega), $5 \mu \mathrm{l}$ of Buffer 5X (Promega), $0.25 \mu \mathrm{l}$ of $5 \mu \mathrm{M}$ for each primer, $5 \mu \mathrm{l}$ of dNTPs $5 \mathrm{mM}, 2 \mu \mathrm{l}$ of template DNA and $15.8 \mu \mathrm{l}$ of nuclease free water. Standard cycling parameters were an initial denaturation step at $94^{\circ} \mathrm{C}$ for $3 \mathrm{~min}, 35$ cycles of denaturation at $94^{\circ} \mathrm{C}$ for $45 \mathrm{~s}$, annealing for $45 \mathrm{~s}$ at different temperatures depending on the primer set $\left(50^{\circ}\right.$ for $\mathrm{rpb} 2,53^{\circ}$ for $\mathrm{V} 9$, and $55^{\circ} \mathrm{C}$ for ITS and gpd), and elongation at $72^{\circ} \mathrm{C}$ for 1 min, followed by a final elongation step at $72^{\circ} \mathrm{C}$ for 10 min. Post-cycling, samples were held at $4^{\circ} \mathrm{C}$.

PCR products were loaded onto a $1.25 \%$ standard agarose gel for electrophoresis $(20 \mathrm{~min}$ at $100 \mathrm{~W})$. Gels were stained with ethidium bromide and photographed under ultraviolet light. Unsuccessfully amplified samples were subjected to multiple amplifications at various DNA concentrations. Sequencing was done by MilleGen (Labège, France).

\section{Alignment and phylogenetic analyses}

Sequences were manually edited using Sequencher 4.8. Gene Codes (Ann Arbor, MI). They were aligned using MAFFT version6 using the LINS-i method with standard settings [65] and subsequently carefully refined by eye. Phylogenetic analyses were conducted on sequence datasets from individual and combined DNA regions using maximum likelihood reconstruction with PhyML
[66] and Bayesian inference as implemented in MrBayes 3.1.2 [67].

MAXIMUM LIKELIHOOD

In PhyML, trees were constructed for each DNA region using the most general time-reversible model of nucleotide evolution with Gamma distributed errors on mutation rates $(\mathrm{GTR}+\mathrm{G})$ and node support was estimated by using the approximate likelihood-ratio test (alrt), a much faster method for estimating branch support than either the bootstrap or Bayesian posterior probabilities [51].

\section{BAYESIAN INFERENCE}

Modeltest 3.7 [68] was run for all data sets (individual and combined) to select a model of sequence evolution. Appropriate DNA substitution models and its parameters were determined based on the comparisons of negative log likelihood values in Modeltest 3.7 [69] implemented in PAUP*4.0b10 [70]. Likelihood and prior settings were changed to meet with the settings corresponding to the models found for each marker. Gaps were coded as missing data. The analyses were initiated with random starting trees and one cold and three incrementally heated Markov chain Monte Carlo (MCMC) chains were run for 10,000,000 generations. Trees were sampled every 1000 generations. The previously determined model of sequence evolution to each data set was applied in the partitioned Bayesian analyses for all combined data sets. For each data set, MCMC runs were repeated twice. Stationarity of the Markov chain was ascertained by plotting likelihood values against number of generations for apparent stationarity. The first 1000 to 2000 trees were discarded as burn-in, and the remaining trees were used to calculate a $50 \%$ majority rule tree and to determine the posterior probabilities for the individual branches.

\section{Estimation of time divergence in Alnus phylogeny}

To estimate divergence times between lineages, the combined data set of ITS and MatK sequences was employed. Rate constancy was tested with a likelihood ratio test [71]. Because the molecular data departed from clock-like evolution, a Bayesian analysis implemented with BEAST ver. 1.4.7 [72] was used under a log-normal relaxed molecular clock [73] and a Yule pure birth model of speciation to estimate the times of divergence and their credibility intervals in the genus Alnus. Posterior distributions of parameters were approximated using two independent MCMC analyses of 10,000,000 generations with 10\% burn-in. Samples from the two runs which yielded similar results were combined and convergence of the chains was checked using the program Tracer 1.3 [74]. Based on a recent Betulaceae phylogeny [75] the divergence between Alnus and 
Betula was assigned with an age of 95 to 105 million year (My).

\section{Additional material}

\section{Additional file 1: List of tree sequences used in this study.}

Sequences of Alnus and Betula species are either generated by the authors or downloaded from GenBank. Vouchers (leaves) are preserved at the Laboratoire Evolution et Diversité Biologique, Toulouse (F).

Additional file 2: List of fungal sequences used in this study. Sequences are either generated by the authors (402 sequences) or downloaded from GenBank or UNITE databases (89 sequences). ${ }^{(1)}$ : not a genuine Alpova but a Melanogaster [28]. Abbreviations of host names: Aacum: Alnus acuminata; Aalnobet: Alnus alnobetula; Acord: Alnus cordata; Afrut: Alnus fruticulosa; Aglut: Alnus glutinosa; Ainc: Alnus incana; Arub: Alnus rubra; Arub?: likely Alnus rubra (M. Berbee, personal communication); Asuav: Alnus alnobetula subsp. suaveolens; Asp. unidentified species of Alnus. Abbreviations of countries: A: Austria; ARG: Argentina; CAN: Canada; CH: Switzerland; CZ: Czech republic; F: France; GB: Great Britain; HU: Hungary; I: Italy; MTN: Montenegro; RUS: Russia; N Norway; SW: Sweden; USA: United States of America.

\section{Abbreviations}

ad int:: ad interim (provisional names for unpublished taxa); Alc:: Alnicola; Alp.: Alpova; ECM: ectomycorrhizal (fungi forming ectomycorrhizae with

Tracheophytes).; My: $10^{6}$ years; s.lat.: sensu lato; s.str.: sensu strict; sect.: section (taxonomic rank); subgen.: subgenus (taxonomic rank)

\section{Acknowledgements}

We thank P. Jargeat and H. Gryta for their comments on earlier versions of the manuscript, F. Chassagne for help with the molecular work, and B. Mouhamadou for the V9 sequences annotation. J. Borovička and M. Berbee are thanked for unpublished information about Russula species and Alpova collections, respectively, J. Alesandri, M. Coulom, L. Hugot and C. Lavoise for field assistance in Corsica, J. Ammirati, G. Corriol, Y. Deneyer, L. Deparis, M. Durand, H. Gamper, J. Guinberteau, P.B. Matheny, B. Perič, U. Peintner, F. Richard, J.-P. Vidonne and J.-J. Wuilbaut for providing important fungal collections for our study, R. Courtecuisse, B. de Foucault and P.A. Schmidt for bibliographic contributions. D. Huges is thanked for correcting English language in our text. This research was financially supported by the région Midi-Pyrénées (grant 2008-2011 to MG) and by the Office de

I'Environnement de la Corse (OEC, Ajaccio, F) to PAM.

\section{Author details}

'Université de Toulouse, UPS, UMR 5174 EDB (Laboratoire Evolution et Diversité Biologique), 118 route de Narbonne, 31062 Toulouse Cedex 4, France. ${ }^{2}$ CNRS, UMR 5174 EDB, 31062 Toulouse Cedex 4, France. ${ }^{3}$ Laboratoire de Botanique, Faculté des Sciences pharmaceutiques et biologiques, Univ Lille Nord de France, 59006 Lille Cedex, France.

\section{Authors' contributions}

$J R$ carried out the molecular phylogenies, and participated in writing of the manuscript as a part of her PhD project. PAM carried out most of the sporocarp samplings and taxonomic identifications, and was deeply involved in the writing of the manuscript along with MG. SM did most of the DNA extractions from sporocarps, the PCRs and the editing of the sequences. MG's contributions are the conception and the coordination of the study, the acquisition and the analysis of the data, and the writing of the manuscript. All authors read and approved the final manuscript.

Received: 10 November 2010 Accepted: 9 February 2011 Published: 9 February 2011

\section{References}

1. Smith SE, Read DJ: Mycorrhizal Symbiosis. 3 edition. London: Academic Press; 2008.
2. Molina R, Massicotte H, Trappe JM: Specificity phenomena in mycorrhizal symbioses: community-ecological consequences and practical implications. In Mycorrhizal symbiosis, an integrative plant-fungal process. Edited by: Allen MF. New York: Chapman and Hall; 1992:357-423.

3. Roy M, Dubois MP, Proffit M, Vincenot L, Desmaris E, Selosse MA: Evidence from population genetics that the ectomycorrhizal basidiomycete Laccaria amethystina is an actual multihost symbiont. Mol Ecol 2008, 17:2825-2838.

4. Kretzer A, Li Y, Szaro T, Bruns TD: Internal transcribed spacer sequences from 38 recognized species of Suillus sensu lato: phylogenetic and taxonomic implications. Mycologia 1996, 88:776-785.

5. Bruns TD, Bidartondo M, Taylor DL: Host specificity in ectomycorrhizal communities: what do exceptions tell us? Integ Comp Biol 2002, 42:352-359

6. Den Bakker HC, Zuccarello GC, Kuyper TW, Noordeloos ME: Evolution and host specificity in the ectomycorrhizal genus Leccinum. New Phytol 2004, 163:201-215.

7. Thompson JN: The geographic mosaic of coevolution Chicago: University of Chicago Press; 2005.

8. Furlow JJ: The systematics of the American species of Alnus (Betulaceae). Rhodora 1979, 81:1-121.

9. Kvaček Z, Teodoridis V: Tertiary macrofloras of the Bohemian Massif: a review with correlations within Boreal and Central Europe. Bull Geosci 2007, 82:383-408.

10. Schmidt PA: Zur Systematik und Variabilität der mitteleuropäischen Erlen (Gattung Alnus Mill.). Mitt Deutsch Dendrol Ges 1996, 82:15-42.

11. Chen Z, Li J: Phylogenetics and biogeography of Alnus (Betulaceae) inferred from sequences of nuclear ribosomal DNA ITS region. Int J PI SCi 2004, 165:325-335.

12. Navarro E, Bousquet J, Moiroud A, Munive A, Piou D, Normand P: Molecular phylogeny of Alnus (Betulaceae), inferred from ribosomal DNA ITS sequences. PI Soil 2003, 254:207-217.

13. Murai S: Phytotaxonomical and geobotanical studies on genus Alnus in Japan (III). Taxonomy of whole world species and distribution of each section. Bull Gov Forest Exp Sta Meguro 1964, 171:1-107.

14. Kovar-Eder J, Kvaček Z, Martinetto E, Roiron P: Late Miocene to Early Pliocene vegetation of southern Europe (7-4Ma) as reflected in the megafossil plant record. Palaeogeogr Palaeoclimatol Palaeoecol 2006, 238:321-339.

15. King RA, Ferris C: Chloroplast DNA phylogeography of Alnus glutinosa (L.) Gaertn. Mol Ecol 1998, 7:1151-1161.

16. Hewitt GM: Post-glacial re-colonization of European biota. Biol J Linn Soc 1999, 68:87-112.

17. Briquet J: Prodrome de la flore corse, comprenant les résultats botaniques de six voyages exécutés en Corse sous les auspices de M. Émile Burnat Tome I. Geneva, Basel: Georg \& Cie; 1910.

18. Ball PW: Alnus Miller. In Flora Europaea Psilotaceae to Platanaceae. Volume I. 2 edition. Edited by: Tutin TG, Heywood VH, Burges NA, Valentine DH, Moore DM. Cambridge University Press; 1993:69-70.

19. Kamruzzahan S: Is Alnus viridis a glacial relict in the Black Forest ? Master thesis Albert-Ludwigs Univ. Freiburg; 2003 [http://www.freidok.uni-freiburg. de/volltexte/1189/pdf/Is_Alnus_viri.pdf].

20. Contandriopoulos J: La flore orophile de la Corse: origines, rapports avec celle des Alpes et des montagnes de l'Europe méridionale. Actes du colloque sur la flore et la végétation des chaines alpine et jurassienne. Annales littéraires de l'université de Besançon Besançon: Presses Universitaires de Franche-Comté; 1971, 205-222.

21. Schönswetter $P$, Tribsch A: Vicariance and dispersal in the alpine perennial Bupleurum stellatum L. (Apiaceae). Taxon 2005, 54:725-732.

22. Molina R: Ectomycorrhizal specificity in the genus Alnus. Can J Bot 1981, 59:325-334.

23. Brunner I, Brunner F, Laursen GA: Characterization and comparison of macrofungal communities in an Alnus tenuifolia and an Alnus crispa forest in Alaska. Can J Bot 1992, 70:1247-1258.

24. Miller $S L$, Koo CD, Molina R: Characterization of red alder mycorrhizae: a preface to monitoring belowground ecological responses. Can J Bot 1991, 69:516-531.

25. Becerra A, Zak MR, Horton TR, Micolini J: Ectomycorrhizal and arbuscular mycorrhizal colonization of Alnus acuminata from Calilegua National Park (Argentina). Mycologia 2005, 15:525-531.

26. Tedersoo L, Suvi T, Jairus T, Ostonen I, Pölme S: Revisiting ectomycorrhizal fungi of the genus Alnus: differential host specificity, diversity and determinants of the fungal community. New Phytol 2009, 182:727-735. 
27. Kennedy PG, Hill LT: A molecular and phylogenetic analysis of the structure and specificity of Alnus rubra ectomycorrhizal assemblages. Fungal Ecol 2010, 3:195-204.

28. Moreau PA, Rochet J, Richard F, Manzi S, Chassagne F, Gardes M: Alnusassociated species of Alpova and Melanogaster (Boletales, Paxillaceae) in Europe. Cryptog Mycol 2011.

29. Trappe J: Fungus associates of ectotrophic mycorrhizae. Bot Rev 1962, 28:538-606.

30. Moser M: Some aspects of Cortinarius associated with Alnus. J JEC 2004, 3:47-101.

31. Mohatt KR, Cripps CL, Lavin M: Ectomycorrhizal fungi of whitebark pine (a tree in peril) revealed by sporocarps and molecular analysis of mycorrhizae from treeline forests in the Greater Yellowstone Ecosystem. Botany 2008, 86:14-25.

32. Moreau PA, Peintner U, Gardes M: Phylogeny of the ectomycorrhizal mushroom genus Alnicola (Basidiomycota, Cortinariaceae) based on rDNA sequences with special emphasis on host specificity and morphological characters. Mol Phylogen Evol 2006, 38:794-807.

33. Moreau PA: A nomenclatural revision of the genus Alnicola. Fungal Div 2005, 20:121-155.

34. Horak E: Röhrlinge und Blätterpilze in Europa - unter der Mitarbeit von Anton Hausknecht (Bolbitiaceae) und P.A. Moreau (Alnicola). Heidelberg: Elsevier Spektrum Akademischer; 2005.

35. Moreau PA, Mleczko P, Ronikier M, Ronikier A: Rediscovery of Alnicola cholea (Cortinariaceae): taxonomic revision and description of its mycorrhiza with Polygonum viviparum. Mycologia 2006, 98:468-478

36. Romagnesi $\mathrm{H}$ : Description de quelques espèces d'Agarics ochrosporés. Bull Trimestriel Soc Mycol France 1942, 58:121-169.

37. Moreau PA, Garcia G: Alnicola salabertii, sp. nov., mycorhizique d'Alnus cordata, et deux autres Alnicola à petites spores. Bull Trimestriel Soc Mycol France 2005, 120:273-292.

38. Grubisha LC, Bergemann SE, Bruns TD: Host islands within the California Northern Channel Islands create fine-scale genetic structure in two sympatric species of the symbiotic ectomycorrhizal fungus Rhizopogon. Mol Ecol 2007, 16:1811-1822.

39. Binder M, Hibbett DS: Molecular systematics and biological diversification of Boletales. Mycologia 2006, 98:971-981

40. Halász K: Különböző stressztűrőképességű nagygombanemzetségek Kárpát-medencei leletanyagának molekuláris azonosítása és rendszerezése. PhD Thesis University of Budapest; 2008 [http://teo.elte.hu/ minosites/ertekezes2009/halasz_k.pdf].

41. Perič B, Moreau PA: Melanogaster luteus, un hypogé rare retrouvé au Monténégro. Mycol Montenegrina 2010, 12:77-83.

42. Buyck B, Hofstetter $V$, Eberhardt U, Verbeken A, Kauff F: Walking the thin line between Russula and Lactarius: the dilemma of Russula subsect. Ochricompactae. Fungal Div 28:15-40.

43. Heilmann-Clausen J, Verbeken A, Vesterholt J: The genus Lactarius. Fungi of Northern Europe 2 Copenhagen: The Danish Mycological Society; 1998.

44. Basso MT: Lactarius Pers. Fungi Europaei 7. Alassio: Mykoflora; 1999.

45. Hesler LR, Smith AH: North American species of Lactarius Ann Arbor: University of Michigan Press; 1979.

46. Romagnesi H: Étude sur les lactaires de la sous-section des Striatini. Bull Trimestriel Soc Mycol France 1974, 90:139-146.

47. Bon M: Clé monographique du genre Lactarius. Doc Mycol 1980, 10:1-85.

48. Nuytinck J, Verbeken A: Worlwide phylogeny of Lactarius section Deliciosi inferred from ITS and glyceraldehyde-3-phosphate dehydrogenase gene sequences. Mycologia 2007, 99:820-832.

49. Brunner I, Horak E: Mycological analysis of Alnus associated macrofungi in the region of the Swiss National Park as recorded by J. Favre (1960). Mycol Helv 1990, 4:111-139.

50. Banaev EV, Bazant $\mathrm{V}$ : Study of natural hybridization between Alnus incana (L.) Moench, and Alnus glutinosa (L.) Gaertn. J Forest Sci 2007, 53:66-73.

51. Roy BA: Patterns of association between crucifers and their flower-mimic pathogens: host jumps are more common than coevolution or cospeciation. Evolution 2007, 55:41-53.

52. Grubisha LC, Trappe JM, Molina R, Spatafora JW: Biology of the ectomycorrhizal genus Rhizopogon. V. Phylogenetic relationships in the Boletales inferred from LSU rDNA sequences. Mycologia 2001, 93:82-89.

53. Hoeksema JD, Thompson JN: Geographic structure in a widespread plantmycorrhizal interaction: pines and false-truffles. J Evol Biol 2007, 20:1148-1163
54. Geml J, Tulloss RE, Laursen GA, Sazanova NA, Taylor DL: Evidence for strong inter- and intracontinal phylogeographic structure in Amanita muscaria, a wind-dispersed ectomycorrhizal basidiomycete. Mol Phylogen Evol 2008, 48:694-701.

55. Peintner U, Bougher N, Castellano MA, Moncalvo JM, Moser MM, Trappe JM, Vilgalys R: Multiple origins of sequestrate fungi related to Cortinarius (Cortinariaceae). Amer J Bot 2001, 88:2168-2179.

56. Boyle H, Zimdars B, Renker C, Buscot F: A molecular phylogeny of Hebeloma species from Europe. Mycol Res 2006, 110:369-380.

57. Grubisha LC, Trappe JM, Molina R, Spatafora JW: Biology of the ectomycorrhizal genus Rhizopogon Vl. Re-examination of infrageneric relationships inferred from phylogenetic analyses of internal transcribed spacer sequences. Mycologia 2002, 94:607-619.

58. Hedh J, Samson P, Erland S, Tunlid A: Multiple gene genealogies and species recognition in the ectomycorrhizal fungus Paxillus involutus. Mycol Res 112:965-975.

59. Gardes M, Bruns T: ITS primers with enhanced specificity for basidiomycetes - application to the identification of mycorrhizae and rusts. Mol Ecol 1993, 2:113-118.

60. Matheny PB: Improving phylogenetic inference of mushrooms with RPB1 and RPB2 nucleotide sequences (Inocybe; Agaricales). Mol Phylogen Evol 2005, 35:1-20.

61. Johannesson HS, Johannesson KHP, Stenlid J: Development of primer sets to amplify fragments of conserved genes for use in population studies of the fungus Daldinia loculata. Mol Ecol 2000, 9:375-378.

62. Jargeat P, Martos F, Carriconde F, Moreau PA, Gryta H, Gardes M: Phylogenetic species delimitation in ectomycorrhizal fungi and implications for barcoding: the case of the Tricholoma scalpturatum complex (Basidiomycota). Mol Ecol 2010, 19:5216-5320.

63. Gonzales $P$, Labarère J: Sequence and secondary structure of the mitochondrial small-subunit rRNA V4, V6, and V9 domains reveal highly species-specific variations within the genus Agrocybe. App/ Environm Microbiol 1998, 64:4149-4160.

64. Mouhamadou B, Carriconde F, Gryta H, Jargeat P, Manzi S, Gardes M: Molecular evolution of mitochondrial ribosomal DNA in the fungal genus Tricholoma: barcoding implications. Fungal Genet Biol 2008, 45:1219-1226.

65. Katoh $\mathrm{K}$, Kuma K, Toh H, Miyata T: MAFFT version 5: improvement in accuracy of multiple sequence alignment. Nucleic Acid Res 2005, 33:511-518.

66. Guindon S, Gascuel O: A simple, fast, and accurate algorithm to estimate large phylogenies by maximum likelihood. Syst Biol 2003, 52:696-704.

67. Huelsenbeck JP, Ronquist FR: MrBayes: Bayesian inference of phylogeny. Biometrics 2001, 17:754-755.

68. Posada D, Crandall KA: Modeltest: testing the model of DNA substitution. Bioinformatics 1998, 14:817-818.

69. Posada D, Crandall KA: Selecting the Best-Fit Model of Nucleotide Substitution. Syst Biol 2001, 50:580-601.

70. Swofford D: PAUP*. Phylogenetic Analysis Using Parsimony (*and Other Methods). Sinauer Associates, Sunderland, Massachusetts; 2003, Version $4 \mathrm{~d} 10$.

71. Felsenstein J: Phylogenies from molecular sequences: inference and reliability. Annual Rev Genet 1988, 22:521-565.

72. Drummond AJ, Rambaut A: BEAST: Bayesian evolutionary analysis by sampling trees. BMC Evol Biol 2007, 7:214.

73. Drummond AJ, Ho SYW, Phillips MJ, Rambaut A: Relaxed phylogenetics and dating with confidence. PLOS Biol 2006, 4:699-710.

74. Rambaut A, Drummond AJ: Tracer v1.4. 2007 [http://beast.bio.ed.ac.uk/ Tracer].

75. Forest F, Savolainen V, Chase MW, Lupia R, Bruneau A, Crane PR: Teasing apart molecular- versus fossil-based error estimates when dating phylogenetic trees: a case study in the birch family (Betulaceae). Syst Bot 2005, 30:118-133.

doi:10.1186/1471-2148-11-40

Cite this article as: Rochet et al:: Comparative phylogenies and host specialization in the alder ectomycorrhizal fungi Alnicola, Alpova and Lactarius (Basidiomycota) in Europe. BMC Evolutionary Biology 2011 11:40. 